\title{
Rapid, productive and stereoselective hydrogenation of ketones*
}

\author{
Ryoji Noyori† and Takeshi Ohkuma \\ Department of Chemistry and Research Center for Materials Science, \\ Nagoya University, Chikusa, Nagoya 464-8602, Japan
}

\begin{abstract}
RuCl}_{2}$ (phosphine) ${ }_{2}$ (1,2-diamine) complexes act as excellent precatalysts for homogeneous hydrogenation of simple ketones which lack any functionality capable of interacting with the metallic center. This newly devised catalytic system allows preferential saturation of a $\mathrm{C}=\mathrm{O}$ function over a coexisting $\mathrm{C}=\mathrm{C}$ linkage in 2-propanol containing an alkaline base. Furthermore, the stereoselectivity of the reaction is easily controlled by the electronic and steric properties (bulkiness and chirality) of the ligands as well as the reaction conditions.
\end{abstract}

\begin{abstract}
Selective reduction of carbonyl compounds to alcohols has relied heavily on the use of metal hydride reagents. Our goal is to replace such stoichiometric reductions by catalytic hydrogenation, because the latter is obviously more beneficial, particularly for large-scale reactions. Here we describe a very practical homogeneous hydrogenation of ketones catalyzed by $\mathrm{RuCl}_{2}$ (phosphine $)_{2}(1,2$-diamine) and an inorganic base. The precatalysts can be preformed or generated in situ by mixing the phosphine- $\mathrm{RuCl}_{2}$ complex and an appropriate 1,2-diamine in 2-propanol. The reaction is normally conducted at room temperature and at $<8 \mathrm{~atm}$ of hydrogen. The new method shows promise for the synthesis of a wide range of achiral and chiral alcohols from ketonic substrates. This chemistry is entirely different from the BINAP-Ru catalyzed asymmetric hydrogenation of functionalized ketones developed earlier in our laboratories [1].
\end{abstract}

\section{RAPID HYDROGENATION OF SIMPLE KETONES}

Preformed $\mathrm{RuCl}_{2}$ (phosphine) $)_{2}$ (1,2-diamine) complexes serve as stable precatalysts for rapid and productive hydrogenation of ketones. For example, when a $2.1 \mathrm{~m}$ solution of cyclohexanone in 2-propanol containing trans- $\mathrm{RuCl}_{2}\left(\mathrm{P}_{(}\left(\mathrm{C}_{6} \mathrm{H}_{4}-4-\mathrm{CH}_{3}\right)_{3}\right)_{2}\left(\mathrm{NH}_{2}\left(\mathrm{CH}_{2}\right)_{2} \mathrm{NH}_{2}\right)$ and $t-\mathrm{C}_{4} \mathrm{H}_{9} \mathrm{OK}$ (ketone:Ru:base $=100$ 000:1:450) was hydrogenated at $10 \mathrm{~atm}$ of hydrogen at $60{ }^{\circ} \mathrm{C}$ for $2 \mathrm{~h}$, cyclohexanol was produced in $96 \%$ yield [2]. The reaction was extremely rapid with an initial turnover frequency (TOF) [3] of $563000 \mathrm{~h}^{-1}$ (or $156 \mathrm{~s}^{-1}$ ). The Ru complexes are among the most reactive (pre)catalysts known for homogeneous hydrogenation of ketones. The reaction rate and productivity of reaction of the preformed phosphine/diamine complexes are some two orders of magnitude higher than those obtained with the in situ generated complexes [4], while the selectivities (vide infra) of both systems are very similar. Although the real catalyst formed under the hydrogenation conditions remains to be elucidated, we consider that the reducing species is RuHX (phosphine) ${ }_{2}$ (diamine) $(\mathrm{X}=\mathrm{H}$, or OR).

\section{CARBONYL-SELECTIVE HYDROGENATION}

Currently available hydrogenation catalysts, either homogeneous or heterogeneous, are mostly selective for $\mathrm{C}=\mathrm{C}$ functions over $\mathrm{C}=\mathrm{O}$ bonds. Despite extensive efforts for over a century, there are no general catalysts effecting $\mathrm{C}=\mathrm{O}$ selective hydrogenation in the presence of an olefinic linkage [5]. We found that a ternary system consisting of $\mathrm{RuCl}_{2}$ (phosphine) $)_{3}, 1,2$-diamine, and an alkaline base or a system comprising trans- $\mathrm{RuCl}_{2}$ (phosphine $)_{2}$ (1,2-diamine) and an alkaline base meets this requirement.

\footnotetext{
*Lecture presented at the 10th IUPAC Symposium on Organo-Metallic Chemistry Directed Towards Organic Synthesis (OMCOS 10), Versailles, France, 18-22 July 1999, pp. 1381-1547.

$\dagger$ Corresponding author: E-mail: noyori@chem3.chem.nagoya-u.ac.jp
} 
An intermolecular competition experiment using an equimolar mixture of heptanal and 1-octene with $\mathrm{RuCl}_{2}\left(\mathrm{P}_{(}\left(\mathrm{C}_{6} \mathrm{H}_{5}\right)_{3}\right)_{3}$ in a 6:1 2-propanol-toluene mixture at $4 \mathrm{~atm}$ of hydrogen at $28{ }^{\circ} \mathrm{C}$ showed that the terminal olefin is 250 -fold more reactive than the aldehyde. However, when one equiv of $\mathrm{NH}_{2}\left(\mathrm{CH}_{2}\right)_{2} \mathrm{NH}_{2}$ and 2 eq. of $\mathrm{KOH}$ with respect to Ru were added, the aldehyde was hydrogenated 1500 -fold faster than the olefin [6]. The very small quantities of the diamine and the base changed the $\mathrm{C}=\mathrm{C} / \mathrm{C}=\mathrm{O}$ selectivity profile by a factor of 375000 . Under such conditions, benzaldehyde was 450 -fold more reactive than styrene and acetophenone was hydrogenated 1500-fold faster than $\alpha$-methylstyrene (Scheme 1).
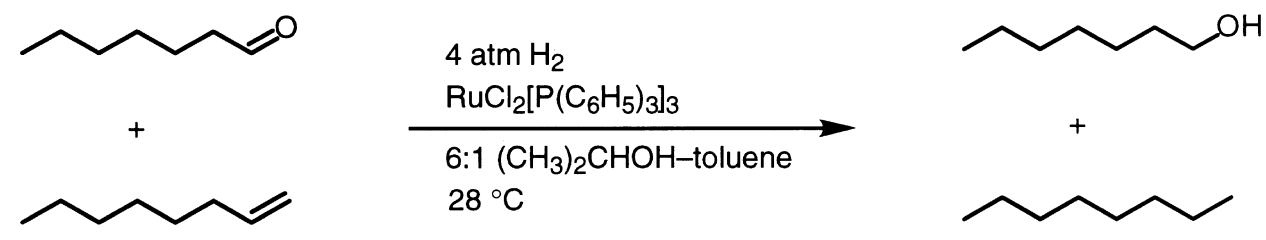

aldehyde:olefin: $\mathrm{Ru}=$ 500:500:1

\begin{tabular}{lcc}
\multicolumn{1}{c}{ additive } & time, min & 1-heptanol:octane \\
\hline no base & 150 & $1: 250$ \\
$\mathrm{NH}_{2}\left(\mathrm{CH}_{2}\right)_{2} \mathrm{NH}_{2}$ and $\mathrm{KOH}$ & 10 & $1500: 1$ \\
$(\mathrm{Ru}:$ diamine: $\mathrm{KOH}=1: 1 \cdot 2)$ & &
\end{tabular}

\section{Scheme 1}

This chemoselective hydrogenation is applicable to a variety of carbonyl compounds having an olefinic or internal acetylenic bond. Certain $\alpha, \beta$-unsaturated aldehydes and ketones are also hydrogenated selectively to allylic alcohols by this method [2,6], The excellent $\mathrm{C}=\mathrm{O}$ selectivity is reminiscent of that attained by stoichiometric $\mathrm{NaBH}_{4}$ reduction (Scheme 2).<smiles>C=CCCCCCCCCC(C)O</smiles>

$97.4 \%$ yield $98.6 \%$ selectivity<smiles>CCCCCCCC/C=C/CO</smiles>

$88 \%$ yield $100 \%$ selectivity<smiles>CC(O)/C=C/c1ccccc1</smiles>

$100 \%$ yield $>99.9 \%$ selectivity

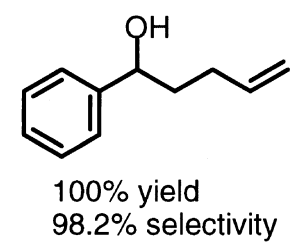<smiles>O=[W]OC/C=C/c1ccccc1</smiles>
$99.8 \%$ selectivity

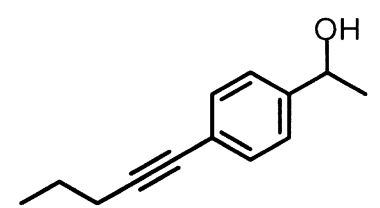

$99.5 \%$ yield $100 \%$ selectivity<smiles>CC(C)=CCC/C(C)=C/CO</smiles>

$92 \%$ yield $100 \%$ selectivity<smiles>CC1=CC(O)CCC1</smiles>

$99.8 \%$ yield $>99.9 \%$ selectivity

Scheme 2

\section{DIASTEREOSELECTIVE HYDROGENATION}

Diastereoselective reduction of ketones has been accomplished mainly with boron-based hydride reagents [7]. The new hydrogenation catalyzed by phosphine/diamine Ru complexes is very useful for this 
purpose. For example, hydrogenation of 4-t-butylcyclohexanone, a conformationally anchored ketone, with the $\mathrm{RuCl}_{2}\left(\mathrm{P}_{(}\left(\mathrm{C}_{6} \mathrm{H}_{5}\right)_{3}\right)_{3}-\mathrm{NH}_{2}\left(\mathrm{CH}_{2}\right)_{2} \mathrm{NH}_{2}-\mathrm{KOH}$ system took place preferentially from the less crowded equatorial direction to give a 98.4:1.6 mixture of cis-4-t-butylcyclohexanol and its trans isomer [8]. Use of preformed trans- $\mathrm{RuCl}_{2}\left(\mathrm{P}_{(}\left(\mathrm{C}_{6} \mathrm{H}_{4}-4-\mathrm{CH}_{3}\right)_{3}\right)_{2}\left(\mathrm{NH}_{2}\left(\mathrm{CH}_{2}\right)_{2} \mathrm{NH}_{2}\right)$ and $t-\mathrm{C}_{4} \mathrm{H}_{9} \mathrm{OK}$ (ketone:Ru:base 50 000:1:250, $10 \mathrm{~atm}, 60^{\circ} \mathrm{C}$ ) effected rapid hydrogenation with a TOF of $178000 \mathrm{~h}^{-1}\left(\right.$ or $\left.49 \mathrm{~s}^{-1}\right)($ Scheme 3) [2].

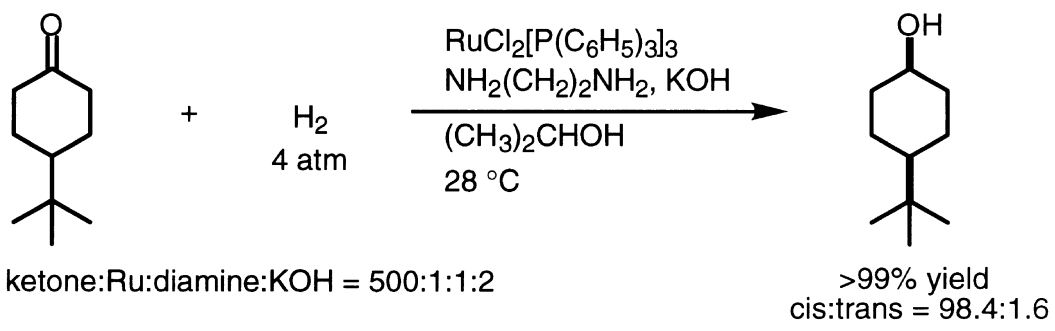

Scheme 3

Some other cyclic ketones can be hydrogenated with a high diastereoselectivity (Scheme 4) [8].
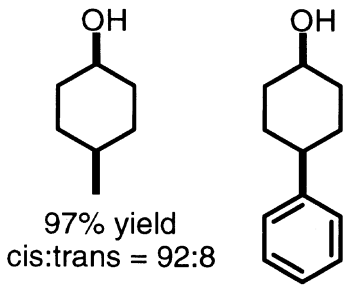

$>99 \%$

$96: 4$<smiles>C[C@H]1CCC[C@@H](O)C1</smiles>
$100 \%$ 4:96<smiles>C[C@H]1CCCC[C@H]1O</smiles>

$95 \%$

$98: 2$<smiles>CC(C)[C@H]1CCCCC1O</smiles>

$>99 \%$ $>99.8: 0.2$

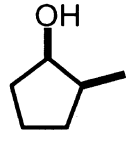

$100 \%$ 99:1<smiles>O[C@H]1CC2CCC1C2</smiles>

$99.9 \%$ endo:exo = 99:1

\section{Scheme 4}

Hydrogenation of 1-phenylethyl ketones, conformationally flexible substrates, displayed a high Cram selectivity [8]. The extent of diastereoselectivity compares well with that obtained with the stoichiometric L-Selectride reagent (Scheme 5) [9].

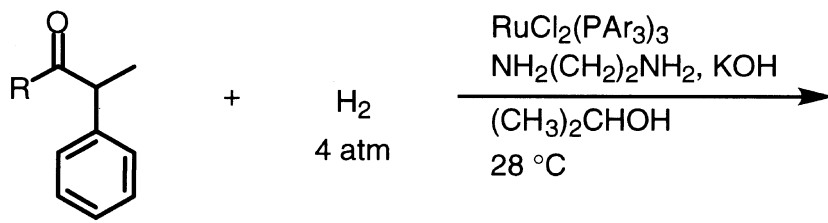<smiles>[R]C(O)[C@H](C)c1ccccc1</smiles>

syn

\begin{tabular}{llcc} 
& & \multicolumn{2}{c}{ alcohol } \\
\cline { 3 - 4 } $\mathrm{R}$ in ketone & $\mathrm{Ar}$ in $\mathrm{PAr}_{3}$ & \% yield & syn:anti \\
\hline $\mathrm{C}_{6} \mathrm{H}_{5}$ & $\mathrm{C}_{6} \mathrm{H}_{5}$ & 99 & $98: 2$ \\
$n-\mathrm{C}_{4} \mathrm{H}_{9}$ & $\mathrm{C}_{6} \mathrm{H}_{5}$ & 96 & $93: 7$ \\
$\mathrm{CH}_{3}$ & $4-\mathrm{CH}_{3} \mathrm{OC}_{6} \mathrm{H}_{4}$ & 99 & $96: 4$
\end{tabular}

Scheme 5 


\section{ENANTIOSELECTIVE HYDROGENATION}

Although various chiral catalysts effect asymmetric reduction, no single catalyst can be universal $[5,10,11]$. This hydrogenation system copes flexibly with the diverse situations by modification of catalyst structures and reaction parameters. A wide variety of chiral Ru catalysts can be obtained by combinations of chiral diphosphine and diamine ligands. Both preformed mixed-ligand complexes and in situ generated complexes are usable [2,4], the former exhibiting a higher turnover number (TON) [3]. Single-crystal X-ray analysis of the structures of the $(R)$-TolBINAP/ $(R, R)$-DPEN Ru complex and the diastereomeric $(R)$-TolBINAP/(S,S)-DPEN complex revealed that both complexes have a distorted octahedral geometry of the Ru center [2]. The $(R, R)$-DPEN ligand forms a $\lambda$ chelate ring, whereas the $S, S$ diamine creates a $\delta$ five-membered ring. ${ }^{1} \mathrm{H}$ and ${ }^{31} \mathrm{P}$ NMR analyses showed that these diastereomers exist as a single conformer in benzene- $d_{6}$ (Scheme 6).<smiles>[R12]c1ccc2ccccc2c1-c1c(P)ccc2ccccc12</smiles>

(R)-BINAP: $\mathrm{Ar}=\mathrm{C}_{6} \mathrm{H}_{5}$

$(R)$-TolBINAP: $\mathrm{Ar}=4-\mathrm{CH}_{3} \mathrm{C}_{6} \mathrm{H}_{4}$

(R)-XyIBINAP: $\mathrm{Ar}=3,5-\left(\mathrm{CH}_{3}\right)_{2} \mathrm{C}_{6} \mathrm{H}_{3}$<smiles>NC(c1ccccc1)c1ccccc1</smiles>

$(R, R)$-DPEN<smiles>COc1ccc(C(N)(c2ccc(OC)cc2)[C@H](N)C(C)C)cc1</smiles>

(R)-DAIPEN<smiles>N[C@@H]1CCCC[C@H]1N</smiles>

$(R, R)$-cyclohexanediamine

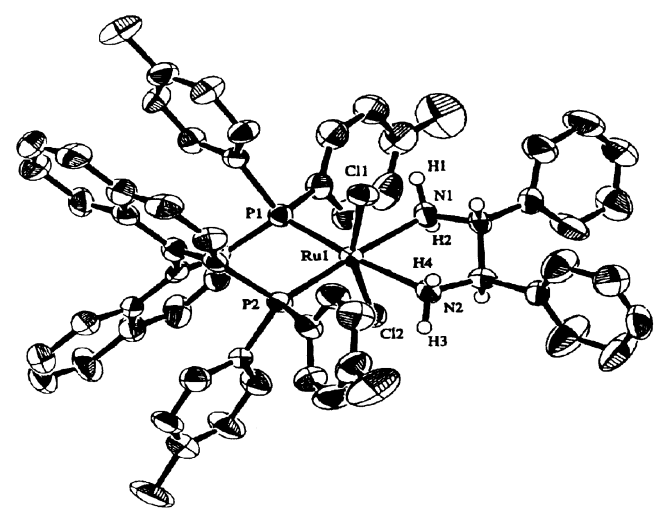

trans- $\mathrm{RuCl}_{2}[(R)$-tolbinap $][(R, R)$-dpen $]$

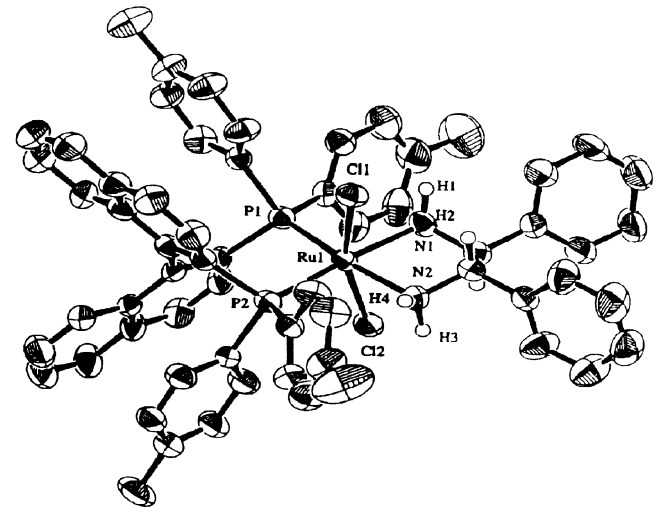

trans- $\mathrm{RuCl}_{2}[(R)$-tolbinap $][(S, S)$-dpen $]$

Scheme 6

Rapid, highly productive asymmetric hydrogenation can be achieved with chiral diphosphine/diamine complexes. When a mixture of acetophenone $(601 \mathrm{~g})$, the TolBINAP/DPEN complex $(2.2 \mathrm{mg})$, and $t$ - $\mathrm{C}_{4} \mathrm{H}_{9} \mathrm{OK}(5.6 \mathrm{~g})$ in 2-propanol $(1.5 \mathrm{~L})$ was stirred under $45 \mathrm{~atm}$ of hydrogen at $30^{\circ} \mathrm{C}$ for $48 \mathrm{~h}$, the $R$ alcohol was obtained in $80 \%$ enantiomer excess and in $100 \%$ yield. The TON was at least 2400000 , while the TOF at $30 \%$ conversion was $228000 \mathrm{~h}^{-1}$ (or $63 \mathrm{~s}^{-1}$ ) [2]. The enantioselectivity was greatly improved by the use of the $(S)$-XylBINAP/(S)-DAIPEN complex (ketone:Ru: $t-\mathrm{C}_{4} \mathrm{H}_{9} \mathrm{OK}=100000: 1: 400,8 \mathrm{~atm}$, $28^{\circ} \mathrm{C}$ ), giving $(R)-1$-phenylethanol in $99 \%$ enantiomer excess (Scheme 7) [12].

With the XylBINAP/DAIPEN Ru catalyst, various $2^{\prime}-, 3^{\prime}-$, and $4^{\prime}$-substituted acetophenones have been hydrogenated with high enantioselectivity. This hydrogenation permits many ring substituents including $\mathrm{F}, \mathrm{Cl}, \mathrm{Br}, \mathrm{I}, \mathrm{CF}_{3}, \mathrm{OCH}_{3}, \mathrm{COOCH}\left(\mathrm{CH}_{3}\right)_{2}, \mathrm{NO}_{2}$, and $\mathrm{NH}_{2}$ (Scheme 8) [12].

2,2,2-Trifluoroacetophenone and its derivatives were also hydrogenated in high yield with high enantioselectivity (Scheme 9) [12]. 


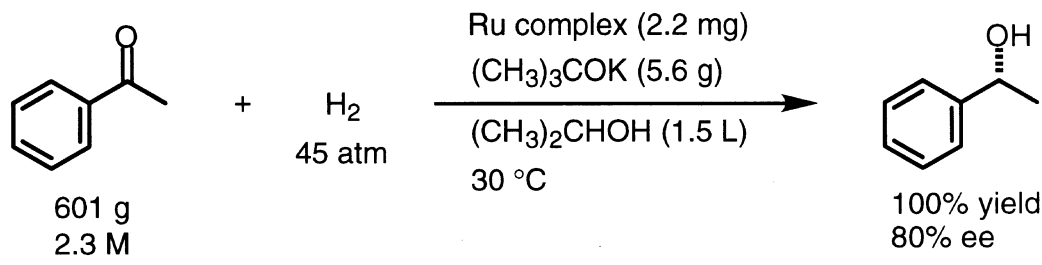

Ru complex:

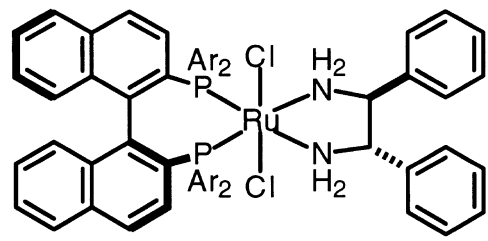

$\mathrm{Ar}=4-\mathrm{CH}_{3} \mathrm{C}_{6} \mathrm{H}_{5}$

trans- $\mathrm{RuCl}_{2}[(S)$-tolbinap $][(S, S)$-dpen]

Scheme 7<smiles>[R]C(=O)c1ccc([X])cc1</smiles>

$$
\begin{aligned}
& \text { Ru complex } \\
& \stackrel{\left(\mathrm{CH}_{3}\right)_{3} \mathrm{COK}}{\longrightarrow} \\
& \underset{\left(\mathrm{CH}_{3}\right)_{2} \mathrm{CHOH}}{26-30{ }^{\circ} \mathrm{C}}
\end{aligned}
$$

\begin{tabular}{|c|c|c|c|c|c|}
\hline $\mathrm{R}(\mathrm{X}=\mathrm{H})$ & $\%$ ee & $\mathrm{X}\left(\mathrm{R}=\mathrm{CH}_{3}\right)$ & $\%$ ee & $X\left(\mathrm{R}=\mathrm{CH}_{3}\right)$ & $\%$ ee \\
\hline $\mathrm{CH}_{3}$ & 99 & $2-, 3-, 4-\mathrm{CH}_{3}$ & $99,100,98$ & $2-, 3-, 4-\mathrm{CF}_{3}$ & $99,99,99.6$ \\
\hline $\mathrm{C}_{2} \mathrm{H}_{5}$ & 99 & $4-n-\mathrm{C}_{4} \mathrm{H}_{9}$ & 98 & $2-, 3,4-\mathrm{CH}_{3} \mathrm{O}$ & $92,99,100$ \\
\hline$\left(\mathrm{CH}_{3}\right)_{2} \mathrm{CH}$ & 99 & 2-, 3-, 4-F & $97,98,97$ & $4-\left(\mathrm{CH}_{3}\right)_{2} \mathrm{CHOCO}$ & 99 \\
\hline \multirow[t]{3}{*}{ cyclo- $\mathrm{C}_{3} \mathrm{H}_{5}$} & 96 & $2-, 4-\mathrm{Cl}$ & 98,98 & $4-\mathrm{NO}_{2}$ & 99.8 \\
\hline & & $2-, 3-, 4-B r$ & $96,99.5,99.6$ & $4-\mathrm{NH}_{2}$ & 99 \\
\hline & & $4-1$ & 99 & & \\
\hline
\end{tabular}

ketone:Ru = 500:1 (1 atm) to 100 000:1

Ru complex $=$ trans- $\operatorname{RuCl}_{2}[(S)$-xylbinap $][(S)$-daipen $]$

\section{Scheme 8}

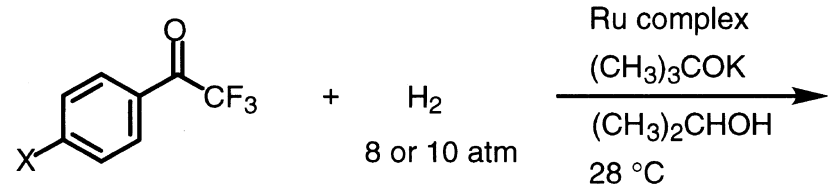

ketone: $\mathrm{Ru}=$ 2000-11 000:1

Ru complex = trans- $\mathrm{RuCl}_{2}[(S)$-xylbinap $][(S)$-daipen $]$<smiles>[X]c1ccc([C@@H](O)C(F)(F)F)cc1</smiles>

\begin{tabular}{lc}
\multicolumn{1}{c}{$\mathrm{X}$} & $\%$ ee \\
\hline $\mathrm{H}$ & 96 \\
$\mathrm{Cl}$ & 94 \\
$\mathrm{Br}$ & 94 \\
$\mathrm{CH}_{3} \mathrm{O}$ & 96
\end{tabular}

\section{Scheme 9}

Asymmetric hydrogenation of alkenyl ketones remained difficult because of conformational flexibility and the presence of two kinds of unsaturated moieties, $\mathrm{C}=\mathrm{C}$ and $\mathrm{C}=\mathrm{O}$. In addition, some simple enones are sensitive to basic conditions. Fortunately, this long-standing problem has been solved by the use of the XylBINAP/DAIPEN Ru complex and the weakly basic $\mathrm{K}_{2} \mathrm{CO}_{3}$ in place of conventional $\mathrm{KOH}$ or 
$t$ - $\mathrm{C}_{4} \mathrm{H}_{9} \mathrm{OK}$. Reaction of benzalacetone $(100 \mathrm{~g})$ in 2-propanol $(150 \mathrm{~mL})$ containing the $(S)$-XylBINAP $/(S)$ DAIPEN complex $(8.3 \mathrm{mg})$ and $\mathrm{K}_{2} \mathrm{CO}_{3}(9.4 \mathrm{~g})$ (ketone: $\mathrm{Ru}=100000: 1,2.7 \mathrm{~m}$ solution) at $80 \mathrm{~atm}$ of hydrogen gave the $R$ alcohol in $97 \%$ enantiomer excess [12]. Enones with various substitution patterns were converted to their corresponding allylic alcohols with high enantiomer excess. $\beta$-Ionone, a dienone, is convertible to $\beta$-ionol in $94 \%$ enantiomer excess. Like in the reaction of aromatic ketones, the combination of the $S$ diphosphine and $S$ diamine (or $R$ and $R$ ) is crucial for obtaining a high level of enantioselection (Schemes 10 and 11).

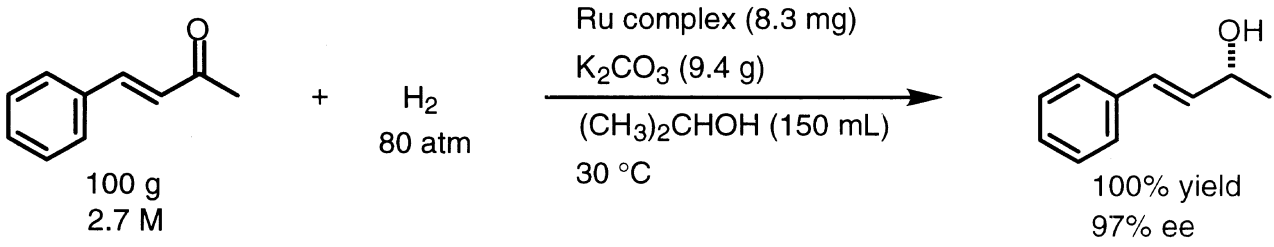

ketone:Ru: $\mathrm{K}_{2} \mathrm{CO}_{3}=100$ 000:1:10 000

Ru complex = trans- $\mathrm{RuCl}_{2}[(S)$-xylbinap $][(S)$-daipen $]$

Scheme 10

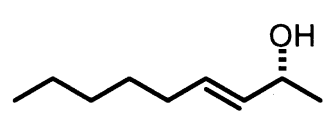

$97 \%$ ee<smiles>CC(C)=C[C@@H](C)O</smiles>

$93 \%$<smiles>CC(C)[C@H](O)/C=C/c1ccccc1</smiles><smiles>C/C=C/[C@H](O)CC(C)C</smiles><smiles>C[C@H](O)/C=C/C1=C([Ge])CCCC1(C)C</smiles><smiles>C[C@H](O)C1=CCCCC1</smiles>

$100 \%$<smiles>C[C@H](O)C1=CCCCCC1[O+]</smiles><smiles>CC1=C([C@H](C)O)CCC1</smiles>

conditions: 8 or 10 atm $\mathrm{H}_{2}$, trans- $\mathrm{RuCl}_{2}\left[(S)\right.$-xylbinap][(S)-diamine] $+\mathrm{K}_{2} \mathrm{CO}_{3}$ or $t-\mathrm{C}_{4} \mathrm{H}_{9} \mathrm{OK}$ in 2-propanol

\section{Scheme 11}

Certain cyclic $\alpha, \beta$-unsaturated ketones can be used as substrates. For example, reaction of 2,4,4trimethyl-2-cyclohexenone in the presence of the $(S)$-TolBINAP/ $(R, R)$-DPEN Ru complex and $t-\mathrm{C}_{4} \mathrm{H}_{9} \mathrm{OK}$ (ketone: $\mathrm{Ru}=10000: 1,10 \mathrm{~atm}, 28^{\circ} \mathrm{C}$ ) produced $(R)$-2,4,4-trimethyl-2-cyclohexenol in $94 \%$ enantiomer excess and in $100 \%$ yield $[2,13]$, No conjugate reduction took place. Here the combination of the $S$ diphosphine and the $R, R$ diamine is necessary for high enantioselection. The $R$ and $S$ cyclohexenols, coupled with the Claisen reaction, are convertible to a series of carotenoid-derived odorants and other bioactive terpenes (Scheme 12) [14].

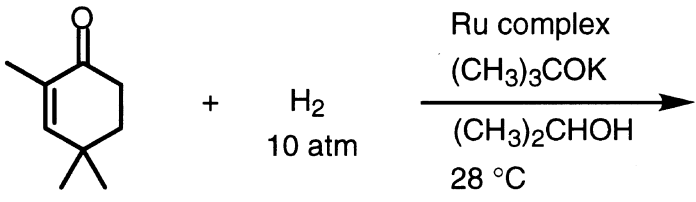

ketone:Ru = 10 000:1

Ru complex $=$ trans-RuCl $2[(S)$-tolbinap $][(R, R)$-dpen $]$<smiles>CC1=CC(C)(C)CC[C@H]1O</smiles>

$100 \%$ yield $94 \%$ ee

\section{Scheme 12}

This important asymmetric hydrogenation is effected by using a racemic diphosphine Ru complex with the aid of a nonracemic 1,2-diamine. Thus, when the cyclohexenone was hydrogenated with ( \pm )$\mathrm{RuCl}_{2}$ (tolbinap)(dmf $)_{n}(S, S)$-DPEN, and $\mathrm{KOH}$ in a 2-propanol-toluene mixture at 8 atm at $0{ }^{\circ} \mathrm{C}$, the $S$ allylic alcohol was obtained in 95\% enantiomer excess and $100 \%$ yield [15]. The observed enantioselectivity reflects the relative turnover numbers of the competing $(R)$-TolBINAP/(S,S)-DPEN and 
(S)-TolBINAP/(S,S)-DPEN catalytic cycles, and the ratio is determined by the relative concentrations and reactivities of the coexisting diastereomeric diphosphine/diamine Ru catalysts. Under this condition $(S, S)$-DPEN selectively activates the $(R)$-TolBINAP-Ru enantiomer of the racemate. Analysis indicates that the $R / S, S$ cycle, with an $S: R$ enantioselectivity of 98:2, turns over 121 times faster than the $S / S, S$ cycle, having an $S: R$ selectivity of 37:63 (Scheme 13).

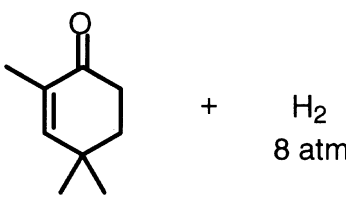

ketone: $\mathrm{Ru}=500: 1$

$$
\begin{aligned}
& \mathrm{RuCl}_{2}[( \pm) \text {-tolbinap }](\mathrm{dmf})_{n} \\
& (S, S) \text {-DPEN, } \mathrm{KOH} \\
& 7: 1\left(\mathrm{CH}_{3}\right)_{2} \mathrm{CHOH} \text {-toluene } \\
& 0{ }^{\circ} \mathrm{C}
\end{aligned}
$$

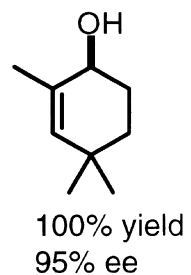

$95 \%$ ee

\section{Scheme 13}

Notably, the relative significance of the diastereomeric cycles, $R / S, S$ and $S / S, S$, as well as the sense and degree of asymmetric induction is highly dependent on the structures of ketonic substrates. When 2 '-methylacetophenone was used as substrate, $(S, S)$-DPEN enhanced the activity of the (S)-TolBINAP-Ru complex more than the $(R)$-TolBINAP enantiomer. The hydrogenation catalyzed by $( \pm)-\mathrm{RuCl}_{2}$ (tolbinap) $(\mathrm{dmf})_{n}$ $(S, S)$-DPEN, and $t-\mathrm{C}_{4} \mathrm{H}_{9} \mathrm{OK}$ afforded $(R)$-1-(2-methylphenyl)ethanol in $90 \%$ enantiomer excess and $100 \%$ yield [15]. In this case, the $S / S, S$ cycle with an $S: R$ enantioselectivity of 1.3:98.7 occurred 13 times faster than the $R / S, S$ cycle, having an $S: R$ selectivity of 54:46 (Scheme 14).<smiles>CC(=O)c1ccccc1C</smiles>

ketone:Ru = 500:1

$$
\begin{aligned}
& \mathrm{RuCl}_{2}[( \pm) \text {-tolbinap }](\mathrm{dmf})_{n} \\
& (\mathrm{~S}, \mathrm{~S}) \text {-DPEN, } \mathrm{KOH} \\
& 7: 1\left(\mathrm{CH}_{3}\right)_{2} \mathrm{CHOH} \text {-toluene } \\
& 0{ }^{\circ} \mathrm{C}
\end{aligned}
$$<smiles>Cc1ccccc1[C@@H](C)O</smiles>

$100 \%$ yield $90 \%$ ee

\section{Scheme 14}

\section{DYNAMIC KINETIC DISCRIMINATION OF STEREOISOMERS}

Stereoisomeric ketones are hydrogenated at different rates. A configurationally labile $\alpha$-substituted ketone undergoes stereomutation easily in basic 2-propanol, leading to a new type of stereoselective hydrogenation based on kinetic discrimination [16].

2,6-Dimethylcyclohexanone is in a rapid equilibrium between the cis and trans isomers (92:8), which can be differentiated kinetically. The trans isomer is rather unreactive because the equatorial approach of the Ru hydride species to the carbonyl carbon is blocked by the axially oriented methyl substituent at the $\alpha$ position. Therefore, hydrogenation of the diastereomeric mixture in the presence of a $\mathrm{RuCl}_{2}\left(\mathrm{P}_{(}\left(\mathrm{C}_{6} \mathrm{H}_{5}\right)_{3}\right)_{3}-\mathrm{NH}_{2}\left(\mathrm{CH}_{2}\right)_{2} \mathrm{NH}_{2}-\mathrm{KOH}$ catalyst system in 2-propanol at $4 \mathrm{~atm}$ gave the cis,cis, trans,trans and cis,trans alcohols in a 98.7:1.1:0.2 ratio [8]. The distribution of the cis,trans isomer $(0.2 \%)$ is much less than the equilibrium population of the trans-dimethyl ketone (8\%) (Scheme 15).

$(-)$-Menthone is in an equilibrium with isomenthone. These epimers were differentiated kinetically by hydrogenation with an $(R)$-BINAP/(S,S)-DPEN Ru catalyst system, leading exclusively to $(+)$-neomenthol (Scheme 16) [8].

Dynamic kinetic resolution provides a useful method to convert racemic $\alpha$-substituted ketones stereoselecively to a single stereoisomer among four possible isomers. Hydrogenation of ( \pm )-2-isopropylcyclohexanone in the presence of an $(S)$-BINAP/ $(R, R)$-DPEN Ru catalyst and $\mathrm{KOH}$ at 4 atm afforded a 99.8:0.2 mixture of the cis-1R,2R alcohol in 93\% enantiomer excess and the trans-1R,2S isomer in $28 \%$ enantiomer excess [8]. Computer-aided analysis of the reaction revealed that: (i) the inherent $1 R, 2 R: 1 S, 2 S: 1 R, 2 S: 1 S, 2 R$ selectivity is $97.26: 2.57: 0.10: 0.07$; (ii) under this reaction condition, the $R$ 


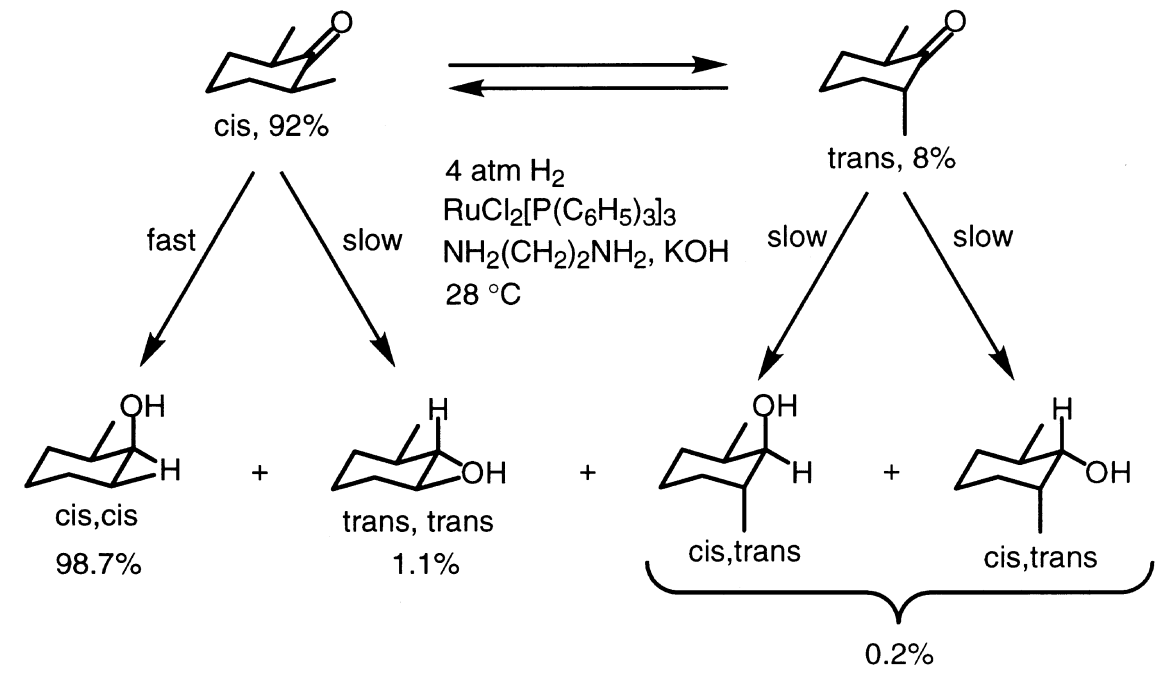

Scheme 15<smiles>CC(C)[C@H]1CC[C@@H](C)CC1=O</smiles>

a mixture of $1 R, 4 S$ and $1 R, 4 R$ isomers ketone:Ru:diamine: $\mathrm{KOH}=500: 1: 1: 20$

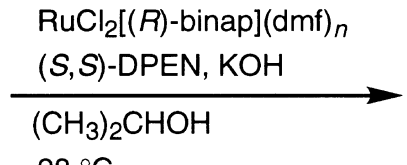

$28^{\circ} \mathrm{C}$<smiles>CC(C)[C@H]1CC[C@@H](C)C[C@H]1O</smiles>

$1 R, 3 S, 4 S$

$100 \%$ yield

Scheme 16

ketone is hydrogenated 36-fold faster than the $S$ enantiomer; (iii) the slow-reacting $S$ ketone undergoes in situ stereochemical inversion 47-fold faster than hydrogenation; (iv) the extent of the substrate-based asymmetric induction (cis/trans) is 192; and (v) the catalyst-controlled asymmetric induction $\left(R^{*} / S^{*}\right)$ is 7.2. The kinetic and stereochemical factors are well coupled to accomplish the diastereo- and enantioselective hydrogenation (Scheme 17).

$( \pm)-$<smiles>CC(C)C1CCCCC1=O</smiles>

ketone:Ru:diamine: $\mathrm{KOH}=500: 1: 1: 20$

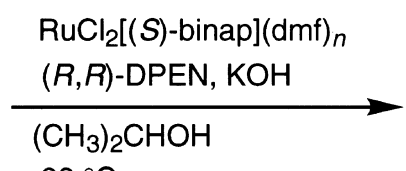

$28^{\circ} \mathrm{C}$<smiles>CC(C)C1CCCCC1O</smiles>

$100 \%$ yield $93 \%$ ee cis:trans $=99.8: 0.2$

Scheme 17

\section{ACKNOWLEDGEMENTS}

We are especially indebted to our able collaborators for their sustained intellectual and experimental efforts. Their names are acknowledged in the cited publications from our laboratories.

\section{REFERENCES}

1 R. Noyori. Asymmetric Catalysis in Organic Synthesis. Chap. 2. Wiley, New York (1994).

2 H. Doucet, T. Ohkuma, K. Murata, T. Yokozawa, M. Kozawa, E. Katayama, A. F. England, T. Ikariya, R. Noyori. Angew. Chem. Int. Eds. 37, 1703 (1998). 
$3 \mathrm{TON}=$ mols product per mol catalyst. $\mathrm{TOF}=\mathrm{TON}$ perh or $\mathrm{s}$.

4 T. Ohkuma, H. Ooka, S. Hashiguchi, T. Ikariya, R. Noyori. J. Am. Chem. Soc. 117, 2675 (1995).

5 T. Ohkuma, R. Noyori. In Transition Metals for Organic Synthesis (M. Beller, C. Bolm, eds), Vol. 2, Chap. 1.1.3. Wiley-VCH, Weinheim (1998), and references cited therein. For $\mathrm{C}=\mathrm{O}$ selective asymmetric transfer hydrogenation, see: R. Noyori, S. Hashiguchi. Acc. Chem. Res. 30, 97 (1997).

6 T. Ohkuma, H. Ooka, T. Ikariya, R. Noyori. J. Am. Chem. Soc. 117, 10417 (1995).

7 Selected reviews: H. C. Brown, S. Krishnamurthy. Tetrahedron 35, 567 (1979); A. P. Davis. In Methods of Organic Chemistry (Houben-Weyl), 4th edn (G. Helmchen, R. W. Hoffmann, J. Mulzer, E. Schaumann, eds), Vol. E21d, p. 3988. Thieme, Stuttgart (1995); H. C. Brown, P. V. Ramachandran. In Reductions in Organic Synthesis (A. F. Abdel-Magid, ed.), Chap. 1. American Chemical Society, Washington, DC (1996), and references cited therein.

8 T. Ohkuma, H. Ooka, M. Yamakawa, T. Ikariya, R. Noyori. J. Org. Chem. 61, 4872 (1996).

9 H. C. Brown, S. Krishnamurthy. J. Am. Chem. Soc. 94, 7159 (1972); S. Krishnamurthy, H. C. Brown. J. Am. Chem. Soc. 98, 3383 (1976).

10 E. J. Corey, C. J. Helal. Angew. Chem. Int. Eds. 37, 1986 (1998), and references cited therein.

11 T. Ohkuma, R. Noyori. In Comprehensive Asymmetric Catalysis (E. N. Jacobsen, A. Pfaltz, H. Yamamoto, eds), Vol. 1, Chap. 6.1. Springer, Berlin (1999).

12 T. Ohkuma, M. Koizumi, H. Doucet, T. Pham, M. Kozawa, K. Murata, E. Katayama, T. Yokozawa, T. Ikariya, R. Noyori. J. Am. Chem. Soc. 120, 13529 (1998).

13 T. Ohkuma, H. Ikehira, T. Ikariya, R. Noyori. Synlett 467 (1997).

14 K. Mori, P. Puapoomchareon. Liebigs Ann. Chem. 1053 (1991). R. Croteau, F. Karp. In Perfumes: Art, Science and Technology (P. M. Müller, D. Lamparsky, eds), Chap. 4. Blackie Academic \& Professional, London (1991).

15 T. Ohkuma, H. Doucet, T. Pham, K. Mikami, T. Korenaga, M. Terada, R. Noyori. J. Am. Chem. Soc. 120, 1086 (1998). See also: K. Mikami, T. Korenaga, M. Terada, T. Ohkuma, T. Pham, R. Noyori. Angew. Chem. Int. Eds. 38, 495 (1999), and references cited therein.

16 M. Kitamura, M. Tokunaga, R. Noyori. J. Am. Chem. Soc. 115, 144 (1993). M. Kitamura, M. Tokunaga, R. Noyori. Tetrahedron 49, 1853 (1993). R. Noyori, M. Tokunaga, M. Kitamura. Bull. Chem. Soc. Jpn. 68, 36 (1995). 